\title{
Selectivity of pre-emergence herbicides in potato cv. Innovator
}

\author{
José Magno Q Luz; Luciano F da Fonseca; Ivaniele N Duarte
}

Universidade Federal de Uberlândia (UFU), Uberlândia-MG, Brazil; jmagno@ufu.br; lffagro@gmail.com; ielenahas@yahoo.com.br

\begin{abstract}
Herbicide tolerance differs among potato cultivars. Thus, preemergence herbicides in potatoes need to be studied. We evaluated weed control, selectivity and potato yield of cv. Innovator with the herbicides clomazone, metribuzin and linuron. The experimental design was randomized blocks with four replications. One experiment was installed in 2014 (experiment 1, 5 treatments) and another in 2015 (experiment 2, 7 treatments), irrigated by central pivot in PerdizesMG, Brazil. In experiment 1 treatments consisted of a control (T1), a hoed control (T2), clomazone (360 $\left.\mathrm{g} \mathrm{ha}^{-1}\right)$ (T3), metribuzin (480 g $\left.\mathrm{ha}^{-1}\right)(\mathrm{T} 4)$, and linuron $\left(990 \mathrm{~g} \mathrm{ha}^{-1}\right)(\mathrm{T} 5)$. The treatments in experiment 2 repeated those in experiment 1 (T1 to T5) and added clomazone + metribuzin $\left.\left(360+480 \mathrm{~g} \mathrm{ha}^{-1}\right)\right)(\mathrm{T} 6)$, and clomazone + linuron $(360+$ $\left.990 \mathrm{~g} \mathrm{ha}^{-1}\right)$ (T7). We determined the number of stems per meter, length of longest stems, phytotoxicity, weed control, soluble solids content (\%), yield and classification of tubers. The herbicides, either by themselves or in combination with another herbicide, provided $100 \%$ control of Eleusine indica and Digitaria horizontalis. Clomazone by itself or in combination with metribuzin or linuron provided the best control of Commelina benghalensis. Plots treated with clomazone presented phytotoxicity symptoms at 10 days after emergence (DAE); however, the plants recovered from these symptoms at 30 DAE. Metribuzin reduced soluble solids content, which affects industrial yield. The herbicides significantly influenced potato yield. In, 2014, the greatest "total" yields were observed in treatments with linuron $\left(34.48 \mathrm{~g} \mathrm{ha}^{-1}\right)$ while the greatest "special" potato yields were achieved with clomazone (20.21 $\left.\mathrm{g} \mathrm{ha}^{-1}\right)$ and linuron $\left(21.13 \mathrm{~g} \mathrm{ha}^{-1}\right)$. In 2015, the greatest "total" yields were observed in treatments with clomazone ["special" (20.98 t ha-1) and "total" (35.11 t ha- $\left.{ }^{-1}\right)$ ] and metribuzin ["special" (20.85 $\left.\mathrm{t} \mathrm{ha}^{-1}\right)$ and "total" (35.45 $\left.\mathrm{g} \mathrm{ha}^{-1}\right)$ ] followed by clomazone+linuron (30.95 $\left.\mathrm{g} \mathrm{ha}^{-1}\right)$. Therefore, while metribuzin and linuron controlled Eleusine indica and Digitaria horizontalis, they may also reduce potato quality. Clomazone may be an option for controlling Eleusine indica, Digitaria horizontalis and Commelina benghalensis without affecting potato yield and soluble solids content.
\end{abstract}

Keywords: Solanum tuberosum, yield, weed.

\section{RESUMO}

Seletividade de herbicidas pré-emergentes na cultura da batata, cv. Innovator

As cultivares de batata podem apresentar diferente tolerância aos herbicidas. O objetivo deste trabalho foi avaliar o controle sobre plantas daninhas, seletividade e a produtividade da cultura da batata cv. Innovator com a aplicação dos herbicidas clomazone, metribuzin e linuron. Foram instalados dois experimentos em área de pivô central na região de Perdizes-MG. O delineamento utilizado foi de blocos casualizados, com quatro repetições. No experimento 1 foram avaliados cinco tratamentos: $\mathrm{T} 1=$ testemunha, $\mathrm{T} 2=$ testemunha capinada, $\mathrm{T} 3=360 \mathrm{~g} \mathrm{ha}^{-1}$ clomazone, $\mathrm{T} 4=480 \mathrm{~g} \mathrm{ha}^{-1}$ metribuzin, $\mathrm{T} 5=990 \mathrm{~g} \mathrm{ha}^{-1}$ linuron. No experimento 2 adicionou-se dois tratamentos: $\mathrm{T} 6=360 \mathrm{~g} \mathrm{ha}^{-1}$ clomazone $+480 \mathrm{~g} \mathrm{ha}^{-1}$ metribuzin e $\mathrm{T} 7=360 \mathrm{~g} \mathrm{ha}^{-1}$ clomazone $+990 \mathrm{~g} \mathrm{ha}^{-1}$ linuron. Foram analisados o número de hastes por metro, comprimento da maior haste, fitotoxicidade, controle de plantas daninhas, teor de sólidos solúveis e a produtividade. Os herbicidas, tanto isolados como em associação, apresentaram controle de $100 \%$ para as espécies Eleusine indica e Digitaria horizontalis. Para o controle de Commelina benghalensis, clomazone isolado ou em associação com metribuzin ou linuron proporcionaram melhor controle. Parcelas tratadas com clomazone apresentaram sintomas de fitotoxicidade aos 10 DAE, porém, as plantas se recuperaram aos 30 DAE. O herbicida metribuzin reduziu o teor de sólidos solúveis dos tubérculos de batata, o que afeta o rendimento industrial. Os herbicidas influenciaram de forma significativa a produtividade da batata. Na safra 2014, os maiores níveis de produtividade "total" foram observados com linuron $(34,48$ $\left.\mathrm{g} \mathrm{ha}^{-1}\right)$ e para batata "especial" clomazone $\left(20,21 \mathrm{~g} \mathrm{ha}^{-1}\right)$ e linuron $\left(21,13 \mathrm{~g} \mathrm{ha}^{-1}\right)$. Na safra 2015, a produtividade da batata foi maior com clomazone [batata "especial" $\left(20,98 \mathrm{~g} \mathrm{ha}^{-1}\right)$ e batata "total" $(35,11 \mathrm{~g}$ $\left.\mathrm{ha}^{-1}\right)$ ] e metribuzin [batata "especial" $\left(20,85 \mathrm{~g} \mathrm{ha}^{-1}\right)$ e batata "total" $\left.\left(35,45 \mathrm{~g} \mathrm{ha}^{-1}\right)\right]$ seguida de clomazone + linuron $\left(30,95 \mathrm{~g} \mathrm{ha}^{-1}\right)$. Portanto, os herbicidas metribuzin e linuron podem ser utilizados no controle de Eleusine indica e Digitaria horizontalis. Entretanto, pode reduzir a qualidade da batata. O clomazone pode ser uma opção no manejo de plantas daninhas na cultura da batata para controle de Eleusine indica, Digitaria horizontalis e Commelina benghalensis sem afetar a produtividade e teor de sólidos solúveis da batata.

Palavras-chave: Solanum tuberosum, produtividade, plantas daninhas.

\section{Received on July 18, 2017; accepted on January 23, 2018}

$\mathrm{W}$ eeds impair commercial potato production (Solanum tuberosum). Weed establishment is favored at the beginning of a crop cycle, especially from planting time to hilling and the closing of the canopy, because of exposed soil, frequent irrigation and the early stage of potato crop development.
Weed should be controlled until the crop sufficiently covers the soil surface and is not subject to further interference (Silva et al., 2011). 
Herbicides can prevent this interference, mainly at the beginning of the crop cycle; however, it is necessary to use chemical compounds that are selective for potato crops. An herbicide is considered selective when it controls weeds without compromising crop development and yield (Oliveira Junior, 2001). Furthermore, and specifically for potato crops, herbicides should not compromise tuber quality as this would decrease the profitability of crop. Metribuzin and linuron are preemergent herbicides that are widely used in potato cultivation and selective for most cultivars (Brazil, 2016). Preemergent applications of metribuzin and linuron have been selective for the Bintje, Monalisa, Atlantic and Achat potato cultivars (Felipe et al., 2006).

Clomazone, which belongs to the isoxazolinonase chemical group, is another herbicide option for potato cultivation and is recommended for preemergent applications to control annual poaceae and some broad-leaf weeds. Clomazone is predominantly absorbed by the apical meristem of seedlings and by roots and stem base of plants, and then translocated via xylem to the leaves, damaging chloroplast, which in turn inhibits formation of photosynthetic pigments and reduces carotene synthesis (Rodrigues \& Almeida, 2011).

The same herbicide can cause different responses in different cultivars. There is currently little information on cv. Innovator's response to pre-emergent herbicides used for weed management. Thus, our objective was evaluate weed control, selectivity and yield in potato cv. Innovator after application of herbicides clomazone, metribuzin and linuron.

\section{MATERIAL AND METHODS}

Two experiments were conducted, the first on the 2014 crop (experiment 1) and another on the 2015 crop (experiment 2), at a potato farm in the municipality of Perdizes-MG, Brazil (19¹9'43' S; 47²3'44"'W; altitude $1054 \mathrm{~m})$. The Innovator cultivar has a crop cycle of 120 days and is mainly marketed towards food-processing companies.
The crop was planted with an eightrow planter (Grimme) and irrigated by central pivot. Type III seeds (diameter 30-40 $\mathrm{mm}$ ) were planted at a depth of $0.12 \mathrm{~m}$, and a spacing of 0.3 meters between plants and $0.8 \mathrm{~m}$ between rows. The soil was classified as typic hapludox (Embrapa, 2013), with clayey texture (55\% clay). In the first experiment, the soil at a depth of $0-20 \mathrm{~cm}$ presented the following chemical characteristics (Embrapa, 1999): pH $(\mathrm{CaCl})=5.6 ; \mathrm{P}$ Resin $=164 \mathrm{mg} \mathrm{dm}^{-3} ; \mathrm{S}=8 \mathrm{mg} \mathrm{dm}^{-3} ; \mathrm{K}=$ $0.2, \mathrm{Ca}=3.5 ; \mathrm{Mg}=0.7$; exchangeable $\mathrm{Al}=0, \mathrm{H}+\mathrm{Al}=2.5 ; \mathrm{SB}=4.41$ and $\mathrm{T}=6.91\left(\mathrm{cmolc} \mathrm{dm}^{-3}\right)$ and organic matter $=2.820 \mathrm{dag}^{\mathrm{k}} \mathrm{k}^{-1}(\mathrm{~V}=64.0 \%)$. In experiment 2, these attributes were: $\mathrm{P}$ Resin $=115 \mathrm{mg} \mathrm{dm}^{-3} ; \mathrm{S}=8 \mathrm{mg} \mathrm{dm}^{-3}$; $\mathrm{K}=0.1, \mathrm{Ca}=3.7 ; \mathrm{Mg}=0.7$; exchangeable $\mathrm{Al}=0, \mathrm{H}+\mathrm{Al}=3.2 ; \mathrm{SB}=4.52$ and $\mathrm{T}=7.7$ $\left.(\mathrm{cmolc} \mathrm{dm})^{-3}\right)$ and organic matter $=2.80$ dag $\mathrm{kg}^{-1}(\mathrm{~V}=58.5 \%)$.

The soil was prepared conventionally by plowing once and leveling twice. Furrows were then plowed by tractor. Afterwards, the soil in both experiments was fertilized with 50-300-80 $\mathrm{kg} \mathrm{ha}^{-1}$ of $\mathrm{N}-\mathrm{P}_{2} \mathrm{O}_{5}-\mathrm{K}_{2} \mathrm{O}$, respectively

Other procedures specific to potato crops, such as top-dressing fertilization, hilling and phytosanitary treatments, were done as necessary and according to the farm's schedule.

The experiments were set up in randomized block design. In experiment 1 , five treatments were tested with four replications totaling 20 plots. The treatments consisted of a control (T1, without weeding and without herbicide application), a hoed control (T2), (360 $\mathrm{g} \mathrm{ha}^{-1}$ clomazone) (T3), (480 $\mathrm{g} \mathrm{ha}^{-1}$ metribuzin) (T4) and (990 $\mathrm{g} \mathrm{ha} \mathrm{h}^{-1}$ linuron) (T5). In experiment 2 , seven treatments were tested with four replications totaling 28 plots. The treatments in experiment 2 repeated those of experiment 1 (T1 to T5) and added two herbicide combinations: (360 $\mathrm{g} \mathrm{ha}^{-1}$ clomazone $+480 \mathrm{~g} \mathrm{ha}^{-1}$ metribuzin) (T6) $360 \mathrm{~g} \mathrm{ha}^{-1}$ clomazone + $990 \mathrm{~g} \mathrm{ha}^{-1}$ linuron) (T7).

Each plot measured $30 \mathrm{~m}^{2}$ (3x10 m), which encompassed an evaluation area of $12.8 \mathrm{~m}^{2}$. The control was without any type of weed control. The hoed control was weeded by hoeing that started soon after emergence and was repeated at 7-day intervals. Herbicides were applied one day after planting (pre-emergence of crops and weeds) using a compressed air sprayer (pressurized to 2.5 bar) connected to a $3 \mathrm{~m}$ bar with six flat-jet nozzles (XR110.02), spaced $0.5 \mathrm{~m}$, and spraying $200 \mathrm{~L} \mathrm{ha}^{-1}$.

Hilling was performed 20 days after emergence, which occurred 10 days after herbicide application. Complete crop development, when the plant canopy covered the soil, occurred 35 days after emergence (DAE). The potato stems were desiccated $105 \mathrm{DAE}$ by applying $2.0 \mathrm{~L} \mathrm{ha}^{-1}$ of Gramoxone (active ingredient $=$ paraquat).

The number of potato stems per meter, length of longest stem, herbicide phytotoxicity and weed control were determined at 10 and 30 DAE. Because hilling occurred 20 days after emergence (30 DAP), the evaluations were carried out before hilling (10 DAE) and then after both hilling and complete canopy coverage of the soil were achieved. The crop was harvested and the yield, commercial classification and soluble solids content $(\%)$ were determined at the end of the crop cycle (120 DAE).

The number of potato stems per meter was determined by counting all the emerged stems within 5 meters of the two central rows of each plot, totaling 10 linear meters. Afterwards, data were transformed into stems $/ \mathrm{m}$. The length of the longest stem was evaluated by averaging the distance from soil to the last node in 10 randomly obtained plants per plot. Herbicide phytotoxicity was assessed by identifying chlorosis, necrosis, discoloration, size reduction, atrophy and deformations on a scale from zero to 100 , where zero meant no symptoms of crop damage and 100 signified crop death. Weed control was evaluated on a scale from zero to 100 , where zero meant no weed control and 100 meant complete weed death.

Soluble solids content was determined using the densimeter technique, which consists of removing a $3.63 \mathrm{~kg}$ sample of tubers from each plot. The mass of each of these samples was then determined by immersing them in a tank with 100 liters water. These estimates were then used to obtain the 
specific mass of each sample, which is related to soluble solids content, and expressed as percentage. Potato yield was determined by manually harvesting all tubers within 5 meters of the two centermost rows in each plot (10 linear meters). After harvesting, tubers were classified and weighed on a mechanical scale. Tubers were classified by diameter as follows: Special (42-70 $\mathrm{mm})$, First (33-42 $\mathrm{mm}$ ) and Second (28-33 mm) classes. Yield data from the evaluation areas were extrapolated to yield in $\mathrm{tha}^{-1}$.

Results were submitted to analysis of variance. In cases where $F$ test was significant, averages were then compared by Tukey test at $5 \%$ significance.

\section{RESULTS AND DISCUSSION}

The number of stems per linear meter did not differ among treatments at both evaluation periods (10 and 30 DAE) and in both 2014 and 2015 crops (Table 1). Therefore, herbicide applications did not affect the number of stems of the potato crop. However, crop management could influence the expression of genetic potential relative to this characteristic. The dry mass of a weed community is significantly correlated and inversely proportional to the number of stems per soybean plant (Meschede et al., 2004). Cox \& Cherney (2011) observed an increase in the number of stems per soybean plant with lower plant density (plants/ row), since, in this case, the open space in the row not only facilitated weed development but also resulted in smaller soybean plants.

The length of the longest stem in the 2014 crop (both evaluation periods) was lower in the metribuzin treatment. However, at 10 DAE in the 2015 harvest, this characteristic was not affected by the pre-emergent herbicides. Nevertheless, at $30 \mathrm{DAE}$, the length of the longest stem was greatest in the hoed control, lowest in the control and intermediate in the herbicide treatments (Table 1). This shows that weed management interferes with potato growth by influencing plant photosynthesis. Interference in the control is due to competition for light, water and nutrients between the crop and weed plants, while in the herbicide treatments, interference results from the potato plant spending energy on metabolizing herbicide instead of using the energy for growth. Reductions in plant size caused by herbicide application are extremely harmful to the physiology of the crop given that each species needs to intercept a certain quantity of light to guarantee natural development and consistent yields (Braz et al., 2012).

In both evaluation periods, herbicide induced phytotoxicity was greatest in the metribuzin treatment (Table 1). The main symptoms were chlorosis and necrosis, which are typical of photosystem II inhibitors (Rodrigues \& Almeida, 2011). Rapparini et al. (1991) demonstrated that pendimethalin and metribuzin caused foliar damage to potatoes.

However, in the early stages of crop development (10 DAE) in the 2015 crop, bleaching of leaf edges was observed in plots treated with clomazone, either alone or in combination. The strongest symptoms of phytotoxicity were observed in treatments $\mathrm{T} 7$ (clomazone + linuron), followed by T6 (clomazone + metribuzin) and T3 (clomazone) (Table 1). Symptoms, such as leaf-edge bleaching and chlorosis, were typical of carotenoid inhibitors that result from inhibited formation of photosynthetic pigments and reduced carotene synthesis (Rodrigues \& Almeida, 2011). However, at $30 \mathrm{DAE}$, no symptoms of phytotoxicity were observed in any treatment (Table 1), demonstrating that symptoms of crop damage are not persistent and that plants are able to recover rapidly due to their increased capacity for metabolizing herbicides, which is associated with morphological changes such as greater cuticle thickness and leaf area. Visual phytotoxicity is dependent on potato cultivar, herbicide type and its application rate, with all symptoms dissipating over the crop cycle (Felipe et al., 2006).

Table 1. Number of stems per meter, length of longest stem (cm), phytotoxicity (\%) in potato crop cv. Innovator evaluated at 10 and 30 days after stem emergence (DAE) using the preemergent herbicides. Perdizes, UFU, 2014/2015.

\begin{tabular}{|c|c|c|c|c|c|c|c|}
\hline \multirow{2}{*}{$\begin{array}{l}\text { Harvest } \\
\text { date }\end{array}$} & \multirow{2}{*}{ Treatments - } & \multicolumn{2}{|c|}{ Stems } & \multicolumn{2}{|c|}{ Length } & \multicolumn{2}{|c|}{ Phytotoxicity } \\
\hline & & 10 & 30 & 10 & 30 & 10 & 30 \\
\hline \multirow{5}{*}{2014} & Control & $11.3^{\text {ns }}$ & $12.9^{\mathrm{ns}}$ & $11.9 \mathrm{~b}$ & $25.2 \mathrm{ab}$ & $0.0 \mathrm{~b}$ & $0.0 \mathrm{~b}$ \\
\hline & Hoed control & 10.6 & 11.1 & $15.0 \mathrm{a}$ & $28.4 \mathrm{a}$ & $0.0 \mathrm{~b}$ & $0.0 \mathrm{~b}$ \\
\hline & Clomazone & 9.5 & 11.9 & $12.2 b$ & $25.9 \mathrm{ab}$ & $0.0 \mathrm{~b}$ & $0.0 \mathrm{~b}$ \\
\hline & Metribuzin & 10.3 & 11.8 & $9.5 \mathrm{c}$ & $21.1 \mathrm{~b}$ & $10.0 \mathrm{a}$ & $4.3 \mathrm{a}$ \\
\hline & Linuron & 12.2 & 12.0 & $13.5 \mathrm{ab}$ & $27.0 \mathrm{ab}$ & $0.0 \mathrm{~b}$ & $0.0 \mathrm{~b}$ \\
\hline DMS & & 2.8 & 3.1 & 1.8 & 6.1 & 1.2 & 0.9 \\
\hline CV (\%) & & 6.4 & 11.4 & 6.4 & 10.6 & 24.3 & 28.0 \\
\hline \multirow{7}{*}{2015} & Control & $6.5^{\text {ns }}$ & $8.1^{\mathrm{ns}}$ & $26.1^{\mathrm{ns}}$ & $38.0 \mathrm{~b}$ & $0.0 \mathrm{c}$ & $0.0^{\text {ns }}$ \\
\hline & Hoed control & 5.9 & 7.5 & 29.1 & $43.6 \mathrm{a}$ & $0.0 \mathrm{c}$ & 0.0 \\
\hline & Clomazone & 6.4 & 7.8 & 26.4 & $39.6 \mathrm{ab}$ & $4.0 \mathrm{~b}$ & 0.0 \\
\hline & Metribuzin & 5.9 & 7.7 & 27.7 & $41.5 \mathrm{ab}$ & $0.0 \mathrm{c}$ & 0.0 \\
\hline & Linuron & 6.5 & 7.7 & 27.7 & $41.6 \mathrm{ab}$ & $0.0 \mathrm{c}$ & 0.0 \\
\hline & $\underset{\text { metribuzin }}{\text { Clomazone }+}$ & 6.1 & 7.0 & 26.6 & $40.0 \mathrm{ab}$ & $4.5 \mathrm{~b}$ & 0.0 \\
\hline & $\begin{array}{c}\text { Clomazone } \\
\text { linuron }\end{array}$ & 6.9 & 8.4 & 25.8 & $38.8 \mathrm{ab}$ & $7.8 \mathrm{a}$ & 0.0 \\
\hline DMS & & 2.1 & 2.6 & 4.1 & 5.5 & 2.0 & 0.0 \\
\hline $\mathrm{CV}(\%)$ & & 14.1 & 14.1 & 6.5 & 6.0 & 37.1 & 0.0 \\
\hline
\end{tabular}

Means followed by the same letter in the column did not differ significantly from each other, Tukey, $\mathrm{p}<0.05$. 
The herbicides clomazone, metribuzin and linuron showed 100\% control efficacy in both crops for Eleusine indica and Digitaria horizontalis, whether used alone or in combination and for Commelina benghalensis in the 2014 crop (Table 2). Controlling these weed species is important because they are some of the most common in potato crops (Blanco, 2008).

However, in the 2015 harvest, the highest levels of control (100\%) of Commelina benghalensis at $10 \mathrm{DAE}$, were in the plots treated with clomazone alone or in combination with metribuzin or linuron. At $30 \mathrm{DAE}$, the best control was observed in the plots treated by the combination of clomazone + linuron, followed by the combination of clomazone + metribuzin. Among treatments with only one herbicide, the efficacy of clomazone was greater than that of metribuzin and linuron (Table 2 ). These data confirm the importance of clomazone and combinations of herbicides with different mechanisms for the control of Commelina benghalensis.

Pre-emergent herbicides are an effective alternative that allow crops to become established before weeds. Determining the predominant species within an area is important for deciding which molecule or molecules to use (Castro et al., 2016). Furthermore, the use of herbicides with different mechanisms of action is recommended and necessary for maintaining the longterm efficiency of weed management (Vidal et al., 2010).

In both crops, soluble solids content (\%) was higher in plots treated with clomazone alone (360 g/ha). However, plots treated with metribuzin, either alone or in combination, had lower soluble solids content (Table 3 ). This occurs because metribuzin inhibits photosynthesis by blocking the transport of electrons in the luminous phase (photosystem II), thereby reducing carbon dioxide $\left(\mathrm{CO}_{2}\right)$ fixation and carbohydrate production.

High soluble solids content or high carbohydrate levels in potatoes, such as cv. Innovator, are greatly valued by the food processing industry. Herbicide weed control reduces competition among plants for light, water and nutrients and enables potato crops to use these resources to produce carbohydrates. The chemical composition of potatoes varies according to factors such as climate, crop management practices, soil conditions, maturity stage, storage and especially fertilization (Pereira \& Costa, 1997).

Herbicides significantly influenced yield and commercial classification of potatoes in our study. In the 2014 harvest, the highest yields for "Total" potatoes were observed with linuron $\left(34.48 \mathrm{t} \mathrm{ha}^{-1}\right)$ and for "Special" potatoes, clomazone (20.21 $\mathrm{t} \mathrm{ha}^{-1}$ ) and linuron

Table 2. Management of weeds in potato crop at 10 and 30 days after stem emergence (DAE) using pre-emergent herbicides. Perdizes UFU, 2014/2015.

\begin{tabular}{|c|c|c|c|c|c|c|c|}
\hline \multirow{2}{*}{ Harvest date } & \multirow{2}{*}{ Treatment } & \multicolumn{2}{|c|}{ C. benghalensis (\%) } & \multicolumn{2}{|c|}{ Eleusine indica (\%) } & \multicolumn{2}{|c|}{ D. horizontalis (\%) } \\
\hline & & 10 DAE & 30 DAE & 10 DAE & 30 DAE & 10 DAE & 30 DAE \\
\hline \multirow{6}{*}{2014} & Control & $0 \mathrm{~b}$ & $0 \mathrm{~b}$ & $0 \mathrm{~b}$ & $0 \mathrm{~b}$ & $0 \mathrm{~b}$ & $0 \mathrm{~b}$ \\
\hline & Hoed control & $100 \mathrm{a}$ & $100 \mathrm{a}$ & $100 \mathrm{a}$ & $100 \mathrm{a}$ & $100 \mathrm{a}$ & $100 \mathrm{a}$ \\
\hline & Clomazone & $100 \mathrm{a}$ & $100 \mathrm{a}$ & $100 \mathrm{a}$ & $100 \mathrm{a}$ & $100 \mathrm{a}$ & $100 \mathrm{a}$ \\
\hline & Metribuzin & $100 \mathrm{a}$ & $100 \mathrm{a}$ & $100 \mathrm{a}$ & $100 \mathrm{a}$ & $100 \mathrm{a}$ & $100 \mathrm{a}$ \\
\hline & Linuron & $100 \mathrm{a}$ & $100 \mathrm{a}$ & $100 \mathrm{a}$ & $100 \mathrm{a}$ & $100 \mathrm{a}$ & $100 \mathrm{a}$ \\
\hline & $\begin{array}{c}\text { Plants } / \mathrm{m}^{2} \text { on } \\
\text { control }\end{array}$ & 7.0 & 12.0 & 4.0 & 5.5 & 2.0 & 4.0 \\
\hline DMS & & 0.0 & 0.0 & 0.0 & 0.0 & 0.0 & 0.0 \\
\hline CV (\%) & & 0.0 & 1.0 & 0.0 & 0.0 & 0.0 & 0.0 \\
\hline Control & & $0.0 \mathrm{c}$ & $0.0 \mathrm{e}$ & $0.0 \mathrm{~b}$ & $0.0 \mathrm{~b}$ & $0.0 \mathrm{~b}$ & $0.0 \mathrm{~b}$ \\
\hline \multirow{6}{*}{2015} & Hoed control & $100 \mathrm{a}$ & $100 \mathrm{a}$ & $100 \mathrm{a}$ & $100 \mathrm{a}$ & $100 \mathrm{a}$ & $100 \mathrm{a}$ \\
\hline & Clomazone & $100 \mathrm{a}$ & $87 b c$ & $100 \mathrm{a}$ & $100 \mathrm{a}$ & $100 \mathrm{a}$ & $100 \mathrm{a}$ \\
\hline & Metribuzin & $75 b$ & $72 d$ & $100 \mathrm{a}$ & $100 \mathrm{a}$ & $100 \mathrm{a}$ & $100 \mathrm{a}$ \\
\hline & Linuron & $75 b$ & $81 \mathrm{c}$ & $100 \mathrm{a}$ & $100 \mathrm{a}$ & $100 \mathrm{a}$ & $100 \mathrm{a}$ \\
\hline & $\underset{\text { metribuzin }}{\text { Clomazone }}+$ & $100 \mathrm{a}$ & 94ab & $100 \mathrm{a}$ & $100 \mathrm{a}$ & $100 \mathrm{a}$ & $100 \mathrm{a}$ \\
\hline & $\begin{array}{c}\text { Clomazone }+ \\
\text { linuron }\end{array}$ & $100 \mathrm{a}$ & $96 a$ & $100 \mathrm{a}$ & $100 \mathrm{a}$ & $100 \mathrm{a}$ & $100 \mathrm{a}$ \\
\hline $\begin{array}{l}\text { Plants } / \mathrm{m}^{2} \text { on } \\
\text { control }\end{array}$ & & 6.4 & 8.6 & 3.4 & 6.5 & 2.3 & 5.1 \\
\hline DMS & & 0.0 & 8.3 & 0.0 & 0.0 & 0.0 & 0.0 \\
\hline CV (\%) & & 0.0 & 5.3 & 0.0 & 0.0 & 0.0 & 0.0 \\
\hline
\end{tabular}

Means followed by same letter in column did not differ significantly from each other, Tukey, $\mathrm{p}<0.05$. 
$\left(21.13\right.$ tha $\left.^{-1}\right)$. In the 2015 harvest, potato yields were highest with clomazone ("Special" potatoes $=20.98 \mathrm{t} \mathrm{ha}^{-1}$ and "Total" potatoes $=35.11 \mathrm{t} \mathrm{ha}^{-1}$ ) and metribuzin ("Special" potatoes $=20.85$ $\mathrm{t} \mathrm{ha}^{-1}$ and "Total" potatoes $=35.45 \mathrm{t}$

ha $^{-1}$ ) followed by clomazone + linuron (30.95 tha-1).

Linuron and metribuzin produced inconsistent yields from one crop to the other while clomazone produced higher yields of "Special" potatoes in

Table 3. Soluble solids (\%) contents in potato cv. Innovator using pre-emergent herbicides. Perdizes UFU, 2014/2015.

\begin{tabular}{lcc}
\hline \multirow{2}{*}{ Treatments } & \multicolumn{2}{c}{ Soluble solids } \\
\cline { 2 - 3 } & Harvest 2014 & Harvest 2015 \\
\hline Control & $18.2 \mathrm{a}$ & $18.7 \mathrm{ab}$ \\
Hoed control & $18.2 \mathrm{a}$ & $18.2 \mathrm{a}$ \\
Clomazone & $18.2 \mathrm{a}$ & $18.8 \mathrm{a}$ \\
Metribuzin & $18.1 \mathrm{~b}$ & $18.1 \mathrm{~b}$ \\
Linuron & $18.2 \mathrm{a}$ & $18.2 \mathrm{ab}$ \\
clomazone + metribuzin & - & $18.1 \mathrm{~b}$ \\
clomazone + linuron & - & $18.3 \mathrm{ab}$ \\
\hline DMS & 0.1 & 0.6 \\
CV $(\%)$ & 0.8 & 1.5 \\
\hline
\end{tabular}

Means followed by same letter in column did not differ significantly from each other, Tukey, $\mathrm{p}<0.05$.

Table 4. Yield and marketable classification of potato (Special (42-70 $\mathrm{mm}$ diameter), First (33-42 mm diameter) and Second (28-33 mm diameter), cv. Innovator using pre-emergent herbicides, Perdizes UFU, 2014/2015.

\begin{tabular}{|c|c|c|c|c|c|}
\hline \multirow{2}{*}{$\begin{array}{l}\text { Harvest } \\
\text { date }\end{array}$} & \multirow{2}{*}{ Treatments } & \multicolumn{4}{|c|}{ Productivity (t/ha) } \\
\hline & & Special & First & Second & Total \\
\hline \multirow{5}{*}{2014} & Control & $17.50 \mathrm{c}$ & $6.22 \mathrm{~d}$ & $3.16 \mathrm{bc}$ & $26.89 c$ \\
\hline & Hoed control & $19.02 \mathrm{~b}$ & $7.20 \mathrm{bc}$ & $2.25 \mathrm{~d}$ & $28.49 b$ \\
\hline & Clomazone & $20.21 \mathrm{a}$ & $6.71 \mathrm{~cd}$ & $2.60 \mathrm{~cd}$ & $29.53 b$ \\
\hline & Metribuzin & $14.88 \mathrm{~d}$ & $7.68 b$ & $3.42 \mathrm{~b}$ & $25.98 \mathrm{c}$ \\
\hline & Linuron & $21.13 \mathrm{a}$ & $8.35 \mathrm{a}$ & $5.00 \mathrm{a}$ & $34.48 \mathrm{a}$ \\
\hline DMS & & 1.12 & 0.54 & 0.73 & 1.28 \\
\hline \multirow[t]{4}{*}{$\mathrm{CV}(\%)$} & & 2.68 & 3.36 & 9.82 & 3.95 \\
\hline & Control & $17.96 \mathrm{~b}$ & $7.76 \mathrm{~b}$ & $2.94 \mathrm{a}$ & $28.66 b c$ \\
\hline & Hoed control & $18.07 \mathrm{~b}$ & $7.65 b$ & $2.96 \mathrm{a}$ & $28.68 \mathrm{bc}$ \\
\hline & Clomazone & $20.98 \mathrm{a}$ & $10.86 \mathrm{a}$ & $3.26 \mathrm{a}$ & $35.11 \mathrm{a}$ \\
\hline \multirow[t]{4}{*}{2015} & Metribuzin & $20.85 \mathrm{a}$ & $11.33 \mathrm{a}$ & $3.27 \mathrm{a}$ & $35.45 \mathrm{a}$ \\
\hline & Linuron & $17.94 b$ & $8.75 b$ & $3.31 \mathrm{a}$ & $30.00 \mathrm{bc}$ \\
\hline & $\begin{array}{l}\text { Clomazone }+ \\
\text { metribuzin }\end{array}$ & $14.67 \mathrm{c}$ & $8.69 b$ & $3.59 \mathrm{a}$ & $26.95 c$ \\
\hline & $\begin{array}{l}\text { Clomazone }+ \\
\text { linuron }\end{array}$ & $17.21 \mathrm{bc}$ & $10.63 a$ & $3.11 \mathrm{a}$ & $30.95 b$ \\
\hline DMS & & 2.55 & 1.35 & 0.78 & 3.24 \\
\hline $\mathrm{CV}(\%)$ & & 6.0 & 6.2 & 10.4 & 4.5 \\
\hline
\end{tabular}

Means followed by same letter in column did not differ significantly from each other, Tukey, $\mathrm{p}<0.05$. both harvests and similar yields to those of the hoed control in 2014 and higher than the hoed control in 2015. Caldiz et al. (2016) found that clomazone (2 L ha $^{-1}$ ) alone or combined with Metribuzin (Clomazone $1 \mathrm{~L} \mathrm{ha}^{-1}+$ Metribuzin $0.75 \mathrm{~L}$ $\mathrm{ha}^{-1}$ ) provided higher total potato yields, higher quality and suppressed weeds.

The weeded control treatment is not $100 \%$ efficient due to the mechanical damage it can cause to plants, which is similar to the phytotoxicity damage caused by herbicides. Therefore, weeding was efficient in the first year but did not show the expected efficiency in the second year. In the second harvest, no statistical difference was observed between the control without weeding and the hoed control (Table 4). Hoeing may have damaged the potato plants, resulting in more energy used for stem growth than for tuber growth (Table 1). We also observed that stem lengths were longer at $30 \mathrm{DAE}$ in the $2^{\text {nd }}$ year.

This demonstrates that manual weeding alone is not efficient and should be harmonized with and complemented by other control methods. Strehmel et al. (2010) found that stress from mechanical damage affects plant physiological and biochemical relationships that, among other consequences, reduces productivity. This reduction in productivity may result from damage to the root system caused by hoeing (Silva et al., 2011), or because hoeing spreads weeds that propagate vegetatively and is therefore only efficient between rows of the primary crop. Other disadvantages are higher operating costs and the risk of spreading plant diseases that penetrate plants through the physical damage caused by hoeing (Castro et al., 2016).

The application of selective preemergent and post-emergent herbicides facilitates weed control within rows, which is not achieved efficiently with other control methods (Oliveira Júnior, 2001).

Metribuzin and linuron increased potato yields but decreased tuber quality (soluble solids content). In addition, these herbicides may be viable options for the control of Eleusine indica and Digitaria horizontalis. Although clomazone caused phytotoxicity at the beginning of crop development, 
the plants recovered by $30 \mathrm{DAE}$ without adverse effects to yield and soluble solids content, and may be an option for controlling Eleusine indica, Digitaria horizontalis and Commelina benghalensis in potato crops.

\section{ACKNOWLEDGEMENTS}

The authors are grateful for support from FMC Química do Brasil LTDA.

\section{REFERENCES}

BLANCO, FMG. 2008. Manejo das plantas daninhas na cultura de batata. Biológico 70 : 19-24.

BRASIL. Ministério da Agricultura Pecuária e Abastecimento. 2016. Sistemas de agrotóxicos fitossanitários: AGROFIT. Available at $:<$ http://agrofit.agricultura.gov.br/agrofit cons/principal_agrofit_cons $>$. Accessed on March 2016.

BRAZ, GBP; OLIVEIRA JUNIOR, RS; CONSTANTIN, J; RAIMONDI, MA; FRANCHINI, LHM; BIFFE, DF; ARANTES, JGZ; TAKANO, HK.2012. Seletividade de amonio-glufosinate isolado e em mistura com pyrithiobac-sodium em algodoeiro transgênico LL $^{\circledR}$. PlantaDaninha 30: 853-860.

CALDIZ, DO; LASA, C; BISIO, PE. 2016. Management of grass and broadleaf weeds in processing potatoes (Solanum tuberosum L.) with clomazone, in the argentinian pampas. American Journal of Plant Sciences 7: 23392348.

CASTRO, YO; CAVALIERI, SD; SANTOS, MP; GOLYNSKI, A; NASCIMENTO, AR. 2016. Manejo integrado de plantas daninhas na cultura do tomate para processamento industrial e para consumo in natura. Scientific Electronic Archives 5: 11-17.

COX, WJ; CHERNEY, JH. 2011. Growth and yield responses of soybean to row spacing and seeding rate. Agronomy Journal 103: 123-128.

EMPRESA BRASILEIRA DE PESQUISA AGROPECUÁRIA. 2013 Sistema brasileiro de classificação de solos. 3. ed. Rio de Janeiro: Embrapa Solos. 353p.

EMPRESA BRASILEIRA DE PESQUISA AGROPECUÁRIA. 1999. Manual de métodos de análise de solo. 2. ed. Rio de Janeiro: Embrapa Comunicação para Transferência de Tecnologia. 212p.

FELIPE, JM; MARTINS, D; COSTA, NV.2006. Seletividade de herbicidas aplicados em pré-emergência sobre cultivares de batata. Bragantia 65: 615-621.

MESCHEDE, DK; OLIVEIRA JUNIOR, RS; CONSTANTIN, J; SCAPIM, CA. 2004. Período anterior à interferência de plantas em soja: estudo de caso com baixo estande e testemunhas duplas. Planta Daninha 22: 239-246.

OLIVEIRA JUNIOR, RS. 2001. Seletividade de herbicidas para culturas e plantas daninhas. In: OLIVEIRA JUNIOR, RS; CONSTANTIN, J. (org). Plantas daninhas e seu manejo. Guaíba: Agropecuária. p.291-314.

PEREIRA, AS; COSTA, DM. 1997. Qualidade e estabilidade de "chips" de batata. Horticultura Brasileira 15: 62-65.

RAPPARINI, G; BARTOLINE, D; FABBRI, M. 1991. Selectivity and degradation time of potato herbicides. Informativo Agropecuário 47: 49-57.

RODRIGUES, BN; ALMEIDA, FS. 2011 Guia de Herbicidas. 6 ed. Londrina. 697p.

SILVA, MCC; BRAUN, H; COELHO, FS. 2011. Manejo e controle de plantas daninhas na cultura da batata. Revista Brasileira de Agropecuária Sustentável 1: 60-67.

STREHMEL, N; PRAEGER, U; KONIG, C; FEHRLE, I; ERBAN, A; GEYER, M; KOPKA, J; DONGEN, JT. 2010. Time course effects on primary metabolism of potato (Solanum tuberosum) tuber tissue after mechanical impact.Postharvest Biology and Technology 56:109-116.

VIDAL, RA; LAMEGO, FP; TREZZI, MM; PRADO, R; BURGOS, NR. 2010. Herbicide resistant weed management using sensitivity analysis of the weed population growth curve. Revista Ecotoxicologia e Meio Ambiente 20: 7-16. 